\title{
Research on Graded Management of Construction Risk Factors of a Subway Station
}

\author{
Xiao LI ${ }^{\mathrm{a}, 1}$ and Jianming $\mathrm{Zhu}^{\mathrm{a}}$ \\ ${ }^{a}$ School of Safety Engineering, North China Institute of Science and Technology, \\ Langfang, Hebei 065201, China
}

\begin{abstract}
Based on a subway station project, this paper puts forward the risk factors in the process of subway construction. The analytic hierarchy process (AHP) is used to establish the risk factor model of metro station. Establishes the risk judgment matrix at all levels by combining the results of expert investigation method. By evaluating the risk factors of the subway station, the weight values of the above risk factors are calculated and sorted. As a result, the risk management system of subway station is put forward.The research results of this method provide a theoretical basis for the project managers to determine the risk factors, and lay a foundation for the smooth progress of the subway station construction project.
\end{abstract}

Keywords. Risk factors, analytic hierarchy process, expert investigation method, risk assessment, risk grading management

\section{General Situation of a Subway Station}

The new subway station is located on the main road of city traffic, above which is a South-North street. The main body of the station is arranged along the street in the South-North direction. The effective platform of the station is $177 \mathrm{~m}$ in total length, $25.3 \mathrm{~m}$ in width and $30 \mathrm{~m}$ in depth. The south side is Commercial Street A. The west side is city hotel. The northeast side is Xinhua Bookstore, and the southeast side is Commercial Street B and cross-street channel. During the construction of the underground excavation of the main structure of the station, there are many surrounding structures, complex underground pipelines and many factors to be considered, as well as many risk factors to be noticed in the construction process. The overall layout of the station is shown in figure 1.

\footnotetext{
${ }^{1}$ Xiao Li, School of Safety Engineering, North China Institute of Science and Technology, Langfang,
} Hebei 065201, China; E-mail: 1091268373@qq.com. 


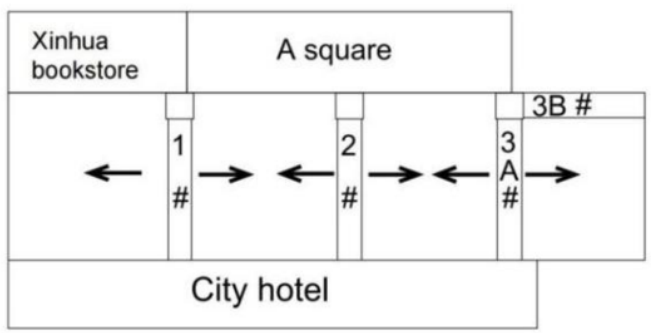

Figure 1. Overall layout of subway station.

The main body of the station is constructed with eight guide tunnels by the method of "PBA" tunnel piles. Four guide tunnels are arranged on the upper and lower layers of the station, which are divided into four axes A, B, C and D and have three sections. Three construction shafts are set in station construction. No. 1 exhaust shaft and No. 2 safety vent are used as shafts for No.1 shaft and No.3 shaft respectively, and No.2 shaft is a new one, whose position intersects with F1 entrance and exit. All shafts are excavated and supported by inverted shaft wall method.

The general construction sequence of the station is firstly to excavate the construction shaft and cross channel, then to construct from three construction channels to both sides at the same time, which will greatly reduce the construction period and improve the construction efficiency.

\section{Construction Risk Factors System of a Subway Station}

According to the comprehensive analysis of the actual construction risk of the new subway station, the specific factors affecting the subway construction safety are obtained, and the analytic hierarchy process structure is constructed [1-3], as shown in table 1 .

Table 1. Subway construction safety evaluation index system.

\begin{tabular}{|c|c|c|c|c|c|}
\hline $\begin{array}{l}\text { The target } \\
\text { layer }\end{array}$ & Rule layer & Index layer & The weight & $\begin{array}{l}\text { The } \\
\text { sorting }\end{array}$ & level \\
\hline \multirow{13}{*}{$\begin{array}{l}\text { Subway } \\
\text { station } \\
\text { construction } \\
\text { risk } \\
\text { assessment } \\
\text { A }\end{array}$} & \multirow{7}{*}{$\begin{array}{l}\text { Peripheral } \\
\text { environmental } \\
\text { risks }\left(B_{1}\right)(0.0953)\end{array}$} & Square $\mathrm{A}\left(\mathrm{C}_{1}\right)$ & 0.0952 & 14 & 1 \\
\hline & & Xinhua bookstore $\left(\mathrm{C}_{2}\right)$ & 0.0836 & 17 & 1 \\
\hline & & City hotel $\left(\mathrm{C}_{3}\right)$ & 0.1304 & 13 & 1 \\
\hline & & Commercial street $\mathrm{A}\left(\mathrm{C}_{4}\right)$ & 0.1970 & 8 & 3 \\
\hline & & Commercial street $\mathrm{B}\left(\mathrm{C}_{5}\right)$ & 0.0517 & 21 & 1 \\
\hline & & Existing station $\left(\mathrm{C}_{6}\right)$ & 0.3904 & 2 & 4 \\
\hline & & Adverse formation $\operatorname{risk}\left(\mathrm{C}_{7}\right)$ & 0.0517 & 22 & 1 \\
\hline & \multirow{6}{*}{$\begin{array}{l}\text { Underground } \\
\text { pipeline } \\
\text { risk }\left(B_{2}\right)(0.1603)\end{array}$} & $\begin{array}{l}\text { Down through the main } \\
\text { station pipeline }\left(\mathrm{C}_{8}\right)\end{array}$ & 0.2216 & 6 & 3 \\
\hline & & Underpass the underground & & & \\
\hline & & $\begin{array}{l}\text { excavation pipeline at the } \\
\text { inlet and outlet }\left(\mathrm{C}_{9}\right)\end{array}$ & 0.3542 & 3 & 3 \\
\hline & & $\begin{array}{l}\text { Underpass the open cut } \\
\text { pipeline at the inlet and } \\
\text { outlet }\left(C_{10}\right)\end{array}$ & 0.0905 & 15 & 2 \\
\hline & & $\begin{array}{l}\text { Replace underground } \\
\text { pipelines }\left(\mathrm{C}_{11}\right)\end{array}$ & 0.0560 & 19 & 1 \\
\hline & & Underpass the transfer & 0.2216 & 7 & 2 \\
\hline
\end{tabular}




\begin{tabular}{|c|c|c|c|c|c|}
\hline $\begin{array}{l}\text { The target } \\
\text { layer }\end{array}$ & Rule layer & Index layer & The weight & $\begin{array}{l}\text { The } \\
\text { sorting }\end{array}$ & level \\
\hline & \multirow{11}{*}{$\begin{array}{l}\text { Risk of construction } \\
\text { method }\left(B_{3}\right)(0.4668)\end{array}$} & channel pipeline $\left(\mathrm{C}_{12}\right)$ & & & \\
\hline & & $\begin{array}{l}\text { Underpass the construction } \\
\text { cross passage pipeline }\left(C_{13}\right)\end{array}$ & 0.0560 & 20 & 1 \\
\hline & & $\begin{array}{l}\text { Excavation risk of side piles } \\
\text { and central columns }\left(C_{14}\right)\end{array}$ & 0.1391 & 12 & 2 \\
\hline & & Pipeline leakage risk $\left(\mathrm{C}_{15}\right)$ & 0.1803 & 9 & 3 \\
\hline & & Hole collapse risk $\left(C_{16}\right)$ & 0.1516 & 10 & 3 \\
\hline & & Risk of broken pile $\left(\mathrm{C}_{17}\right)$ & 0.0877 & 16 & 2 \\
\hline & & Hole offset risk $\left(\mathrm{C}_{18}\right)$ & 0.0432 & 23 & 1 \\
\hline & & Risk of land subsidence $\left(\mathrm{C}_{19}\right)$ & 0.1423 & 11 & 3 \\
\hline & & $\begin{array}{l}\text { The connection between } \\
\text { buckle arch and primary } \\
\text { branch is weak risk }\left(\mathrm{C}_{20}\right)\end{array}$ & 0.2256 & 5 & 3 \\
\hline & & Design change risk $\left(C_{21}\right)$ & 0.0302 & 24 & 1 \\
\hline & & $\begin{array}{l}\text { Subterranean excavation risk } \\
\text { of auxiliary structure }\left(C_{22}\right)\end{array}$ & 0.3420 & 4 & 3 \\
\hline & \multirow[t]{2}{*}{$\begin{array}{l}\text { Station Own } \\
\text { Risk }\left(B_{4}\right)(0.2776)\end{array}$} & $\begin{array}{l}\text { Risk of open cut construction } \\
\text { of accessory structure }\left(C_{23}\right)\end{array}$ & 0.0811 & 18 & 2 \\
\hline & & $\begin{array}{l}\text { The risk of digging main } \\
\text { structure of the station }\left(\mathrm{C}_{24}\right)\end{array}$ & 0.5769 & 1 & 4 \\
\hline
\end{tabular}

\section{Establishment of Risk Assessment Matrix}

\subsection{Calculation of Evaluation Weight Vector $W$}

$$
\mathrm{W}=\left(\mathrm{W}_{1}, \mathrm{~W}_{2}, \cdots, \mathrm{W}_{\mathrm{n}}\right)^{\mathrm{T}}
$$

Analytic hierarchy process to determine the weight vector $\mathrm{w}[4,5]$ methods are: sum method (arithmetic average), square root method (geometric average), characteristic root method, least square method. In order to facilitate the calculation, the arithmetic square method is used to analyze the weight:

$$
\mathrm{W}_{\mathrm{i}}=\frac{1}{\mathrm{n}} \sum_{\mathrm{j}=1}^{\mathrm{n}} \frac{\mathrm{a}_{\mathrm{ij}}}{\sum_{\mathrm{k}=1}^{\mathrm{n}} \mathrm{a}_{\mathrm{ij}}}, \mathrm{i}=1,2, \cdots, \mathrm{n}
$$

\subsection{Analysis of Expert Questionnaire}

According to the expert survey method, the questionnaire survey is conducted, and the scale of 1-9 is introduced. The experts score the factors and calculate the scoring results of each factor, as shown in table 2 .

Table 2. Scoring statistics of construction risk indicators of new Metro Station

\begin{tabular}{llllllllll}
\hline $\begin{array}{l}\text { Rule } \\
\text { layer }\end{array}$ & Score & $\begin{array}{l}\text { Factors } \\
\text { layer }\end{array}$ & Score & $\begin{array}{l}\text { Factors } \\
\text { layer }\end{array}$ & Score & $\begin{array}{l}\text { Factors } \\
\text { layer }\end{array}$ & Score & $\begin{array}{l}\text { Factors } \\
\text { layer }\end{array}$ & Score \\
\hline $\mathrm{B}_{1}$ & 5.14 & $\mathrm{C}_{1}$ & 4.85 & $\mathrm{C}_{7}$ & 3.20 & $\mathrm{C}_{13}$ & 3.83 & $\mathrm{C}_{19}$ & 7.85 \\
$\mathrm{~B}_{2}$ & 5.36 & $\mathrm{C}_{2}$ & 4.50 & $\mathrm{C}_{8}$ & 6.85 & $\mathrm{C}_{14}$ & 7.82 & $\mathrm{C}_{20}$ & 8.33 \\
$\mathrm{~B}_{3}$ & 7.17 & $\mathrm{C}_{3}$ & 5.00 & $\mathrm{C}_{9}$ & 7.33 & $\mathrm{C}_{15}$ & 8.20 & $\mathrm{C}_{21}$ & 4.32 \\
$\mathrm{~B}_{4}$ & 6.64 & $\mathrm{C}_{4}$ & 6.75 & $\mathrm{C}_{10}$ & 4.50 & $\mathrm{C}_{16}$ & 8.00 & $\mathrm{C}_{22}$ & 7.33 \\
& & $\mathrm{C}_{5}$ & 3.20 & $\mathrm{C}_{11}$ & 3.50 & $\mathrm{C}_{17}$ & 7.05 & $\mathrm{C}_{23}$ & 4.26 \\
& & $\mathrm{C}_{6}$ & 8.50 & $\mathrm{C}_{12}$ & 6.12 & $\mathrm{C}_{18}$ & 5.75 & $\mathrm{C}_{24}$ & 8.33 \\
\hline
\end{tabular}




\subsection{AHP is used to Evaluate the Weight of each Index}

According to the safety risk analysis of the subway construction, the order of the relevant degree of each factor and the subway station construction safety is listed in table 1 .

\section{Determination of Membership Function of Evaluation System}

According to the construction safety situation, the comprehensive evaluation index of risk level is divided into $1 \sim 5$ grades: $\mathrm{v}[6-8]=$ \{safe, relatively safe, general, dangerous, extremely dangerous $\}$. The membership function Rij (x) is shown in table 3 .

Table 3. Membership function expression.

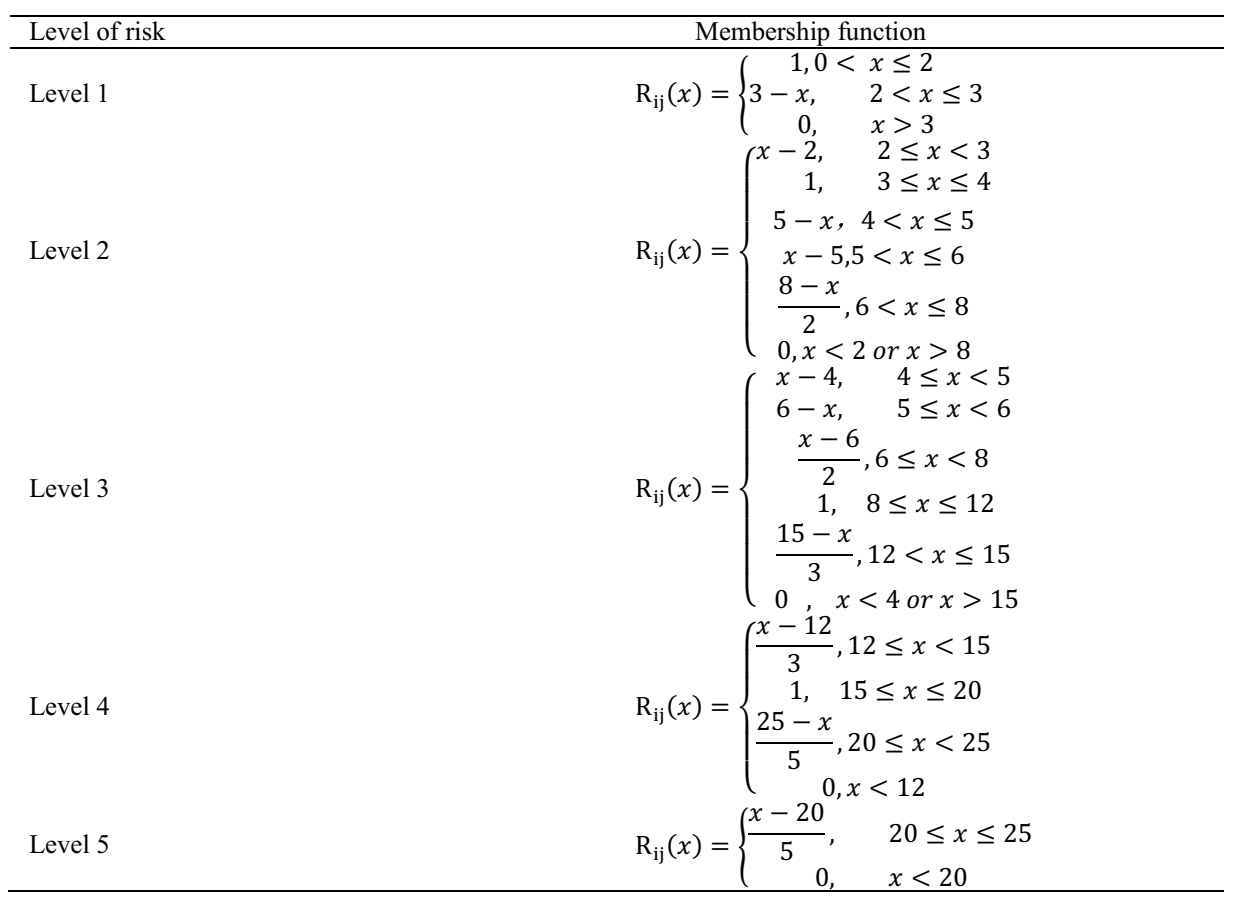

\section{Establishment of Hierarchical Management of Risk Factors}

There are 24 risk events in the risk assessment model mentioned above, which are scored by experts to get $\mathrm{P}$ and $\mathrm{C}$ values, and then put them into the membership function table 3 to judge the risk level of each risk factor, which is divided into five levels, as shown in table 1.

As can be seen from table 1, the structural self-risk engineering and the existing station risk are the highest level risk factors. The commercial street above the station, the main pipeline under the station, the ground subsidence risk and other risk factors 
are the next. The results above provide decision-making basis for safety management of construction site.

\section{Conclusion}

Based on a new subway station, this paper evaluates the safety risk in the construction process by expert investigation and AHP, and obtains the following conclusions:

(1) The occurrence of subway station construction accidents is random, the complexity of development process and the incomplete existing safety reserve. When carrying out safety analysis, many factors cannot be quantified directly. Therefore, the AHP and expert investigation method are needed to make the safety assessment of project construction more scientific;

(2) When the subway station project is constructed, the risk factors risk ranking obtained by the reference analytic hierarchy process can effectively and emphatically carry out the prevention and safety management of construction accidents.

(3) This paper puts forward the dangerous factors and safety grade division of tunnel pile construction in subway station, which is conducive to the scientific decision-making of construction site.

\section{References}

[1] Zhang SB. Research on construction risk management of Zhengzhou Metro Line 5 based on fuzzy comprehensive theory. Henan: North China University of Water Resources and Electric Power; 2018. p. 39.

[2] Wang G, Liu B G and Qi Y. Risk and evaluation of subway construction based on WBS-RBS and fault tree coupling. Chinese Journal of Underground Space and Engineering. 2015 Dec; 11(S2): 772-779.

[3] Zhou NQ, Gao YQ, Huang ZH, Zhang SR. The improved interval analytic hierarchy process (AHP) is used to evaluate the groundwater risk of subway engineering. Journal of Architecture and Civil Engineering. 2017 Nov; 34(06): 21-27.

[4] Chen ZH, Chen JJ and Yang JH. Risk analysis of shield tunnel construction based on fuzzy analytic hierarchy process. Chinese Journal of Underground Space and Engineering. 2013 Dec; 9(06): 1427$1432+1464$.

[5] Ying GZ, Wang PC, Zhu DY, Zhang YL, Qin Z. Improvement of fuzzy analytic hierarchy process method and its application in subway construction risk assessment. Journal of Hefei University of Technology (Natural Science). 2014 Oct; 37(10): 1244-1248.

[6] Kampmann J, Eskesen SD and Summers JW. Risk assessment helps select the contractor for the Copenhagen Metro System. In: editors. Proceedings of the World Tunnel Congress 98 on Tunnels and Metropolises; 1998 Apr 25-30; Sao Paulo, Brazil. Rotterdam(NL): CRC Press; p. 123-128.

[7] Søren DE, Per T, Jørgen K, et al. Guidelines for tunnelling risk management: International tunnelling association, working group No.2. Tunnelling and Underground Space Technology incorporating Trenchless Technology Research. 2004 May; 19(3): 217-237.

[8] Arsalan K and Mohammad S. Subway risks assessment in different construction stages using AHP and TOPSIS. Indian Journal of Science and Technology. 2016 Mar; 9(7). 